\title{
STATISTICAL ANALYSIS OF GREEN ENERGY POWER GENARTION USING BIOGAS METHANATION POWER PLANT
}

\author{
Rajendra Ramchandra Shinde ${ }^{1}$, Ashwini Dilip Patil ${ }^{2}$, Prasad Jaysingh Yadav ${ }^{3}$
}

\author{
${ }^{1}$ HOD, Electrical Engineering Department, Adarsh Institute of Technology Poly-(Vita), Maharashtra, India \\ ${ }^{2}$ Sr. Lecturer, Electrical Engineering Department, Adarsh Institute of Technology Poly-(Vita), Maharashtra, India \\ ${ }^{3}$ Sr. Lecturer, Electrical Engineering Department, Adarsh Institute of Technology Poly-(Vita), Maharashtra, India
}

\begin{abstract}
The paper promotes the inexperienced energy that is being worldwide supported by many countries. inexperienced energy is that the type of energy obtained from non-exhaustible resources. Technologies that promote inexperienced energy embody renewable energy sources, like electricity, alternative energy, wind energy, wave power, heat, bioenergy, periodic event power. The paper has analyzed utilization of bovine dung and human manure waste for electricity generation through a varied case studies on biomethanation station. There square measure or so twenty Million bovine and a couple of Million human population within the within the single district of geographic area. Nearly five hundredth of bovine dung and human manure is being sold-out for agricultural suggests that and also the remaining is drained off into a close-by drain. The drained off bovine dung and human manure will be used for power generation supporting inexperienced energy while not touching nature and fewer carbon emission. The paper has studied the political economy of power generation of Biogas methanation station and has found that it's profitable to utilize the bovine dung and human manure for electricity generation, the capital investment depends on the capability of the plant and payback amount being most four to six years. Besides electricity generation the plant additionally provides bio-manure. It additionally checks pollution and emission of greenhouse gases. The study has urged that such plants ought to be established not solely all told the districts of geographic area however additionally in whole country to assist in electricity generation. the massive farmers ought to represent Non Govt. Organization (NGOs), Consultancy's and aid cluster (SHG) to determine such plants in their various areas. The central and regime provides the required steering and backing for the institution of such plants.
\end{abstract}

Key Words: Green energy, Bioenergy, Bio-methanation, Non Govt. Organization (NGOs), Self-Help Group (SHG) etc...

\section{INTRODUCTION}

The need of electrical power is growing exponentially however the assembly rate lags way behind, thus, leading to power starvation. The impact is a lot of evident within the rural areas instead of the urban or industrial regions. The state of affairs is most wailful that a right away focus is to be paid at this issue. The issues area unit way grave than simply thrilling the agricultural areas, operation and maintenance is another robust task.

Many steps are taken to unravel the on top of drawback. Republic of India has taken spectacular strides in promoting renewable sources of energy for rural electrification mainly wind, little hydropower, biomass and star.

\subsection{Present Solution}

Renewable energy presently contributes 75,000 MW, accounting for concerning $28.35 \%$ of put in power generation capability in Asian nation until September 2015. The first issues driving Indian policy relate to native pollution, energy security and economic and social development imperatives although, of course, there are necessary global climate change co-benefits in terms of lowering carbon emissions.

Turning to rural areas generally, suburbanized applications of renewable energy embody biomass, biogas and alternative energy for such uses as change of state, drying farm turn out, and residential and street lighting); and wind and alternative energy for water pumping.

\subsection{Present Scenario of Energy Sector}

The sector of electrical energy in India had an installed capacity of $278,734 \mathrm{MW}$ as of 30 September 2015. Renewable Power plants deep-seated twenty seventh of total put in capability and Non-Renewable Power Plants deepseated the remaining seventy two.

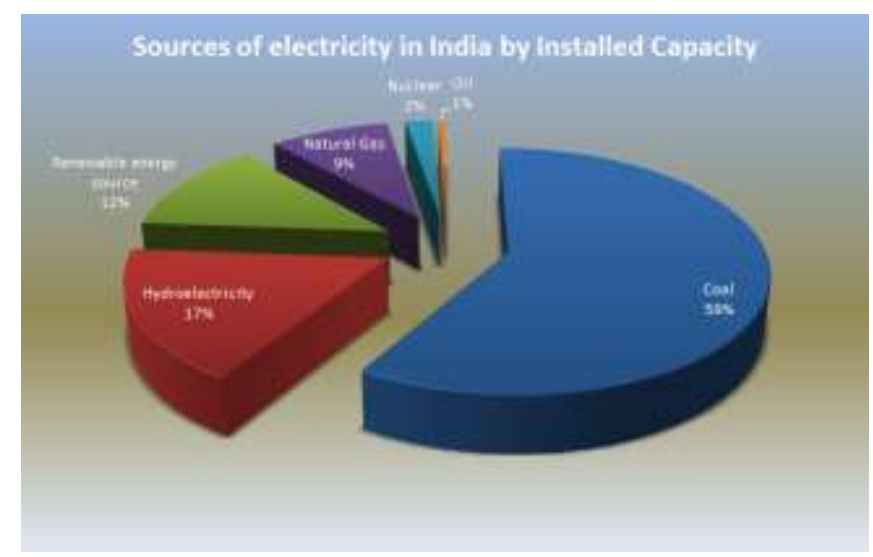

Fig -1: Sources of Electricity 


\subsection{Present Scenario of Renewable Energy Sector}

Renewable energy in Asian nation comes below the view of the Ministry of recent and Renewable Energy. The first country in the world to setup a ministry under nonconventional energy resources was India in, in early Nineteen Eighties. India's accumulative grid interactive or grid tied renewable energy capability has reached 75.05 $\mathrm{GW}$, of that only $1.8 \%$ comes from biomass power generation of total energy put in capability in Asian nation.

Table -1: Total Renewable Energy Installed Capacity

\begin{tabular}{|c|c|}
\hline Source & $\begin{array}{c}\text { Total Installed } \\
\text { Capacity (MW) }\end{array}$ \\
\hline Large Hydro Power & $41,267.00$ \\
\hline Wind Power & $22,465.03$ \\
\hline Solar Power (SPV) & $3,062.68$ \\
\hline Small Hydro Power & $3,990.83$ \\
\hline Biomass Power & $1,365.20$ \\
\hline Bagasse Cogeneration & $2,800.35$ \\
\hline Waste to Power & 107.58 \\
\hline Total & $\mathbf{7 5 , 0 5 8 . 7 4}$ \\
\hline
\end{tabular}

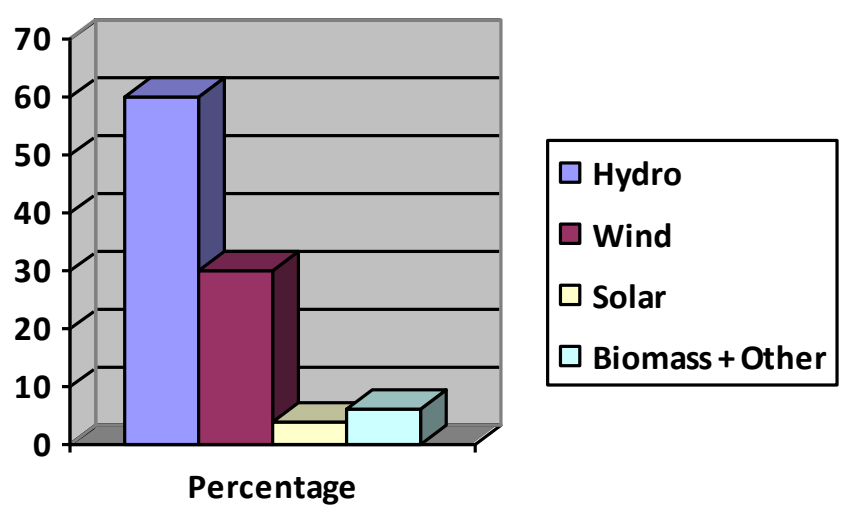

Chart -1: Power Plant comparison

\section{Biogas Methanation (Gas Formation)}

Biogas is generally the mix contents of various gases which is obtained only through breakdown of organic matter in the absence of oxygen content air.

Biogas can be obtained from agricultural waste, human and animal manure, public waste or garbage. It is also being considered as renewable source of energy as it emits very less carbon content. Biogas is produced by anaerobic digestion process by anaerobic bacteria, which includes the digestion of waste or bio-degradable material in the closed system. Biogas contains huge amount of methane $\left(\mathrm{CH}_{4}\right)$ content with carbon gas $\left(\mathrm{CO}_{2}\right)$ and will have little amounts of sulfide $\left(\mathrm{H}_{2} \mathrm{~S}\right)$, wetness and siloxanes.

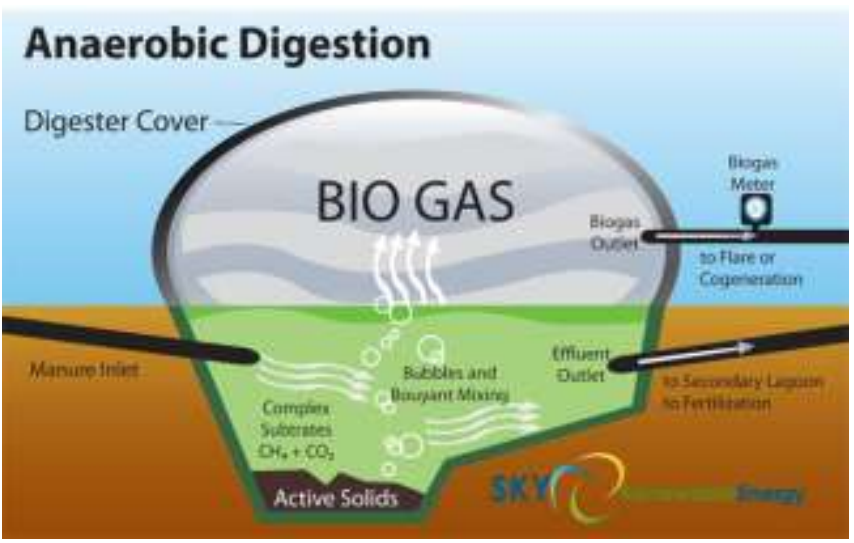

Fig -2: Biogas Formation

The gas composition of methane, hydrogen and carbon monoxide (CO) can combusted with oxygen. This energy which is unleashed in the combustion process permits biogas to be utilized as a fuel. This energy can utilized for many purposes like heating, cooking and also for power generation by using the gas for running the gas engine.

Table -2: Typical composition of biogas

\begin{tabular}{|c|c|c|}
\hline Compound & Formula & $\%$ \\
\hline Methane & $\mathrm{CH}_{4}$ & $50-75$ \\
\hline Carbon dioxide & $\mathrm{CO}_{2}$ & $25-50$ \\
\hline Nitrogen & $\mathrm{N}_{2}$ & $0-10$ \\
\hline Hydrogen & $\mathrm{H}_{2}$ & $0-1$ \\
\hline Hydrogen sulfide & $\mathrm{H}_{2} \mathrm{~S}$ & $0-3$ \\
\hline Oxygen & $\mathrm{O}_{2}$ & $0-0.5$ \\
\hline
\end{tabular}

\subsection{Landfill Gas (LFG)}

Biogas can be obtained as landfill gas-LFG or digested gas, which is actually produced on breakdown of biodegradable waste due to chemical reaction of microbes or organic material beneath the landfill or an anaerobic digester.

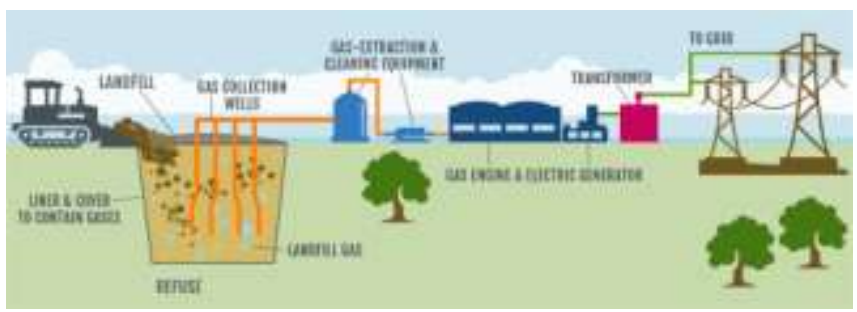

Fig -3: Landfill Gas (LFG)

The anaerobic digester that converts biodegradable waste to biogas energy is referred to as biogas plant. It can be obtained by anaerobic digester i.e., air tight tanks. These plants use the waste energy crops like maize or biodegradable waste, garbage waste. The process of producing the biogas includes the process of transforming 
microorganisms' biomass waste to biogas with huge content of methane and carbon.

This energy can utilized for many purposes like heating, cooking and also for power generation by using the gas for running the gas engine. Now the remaining organic matter or waste of digester which is not being converted to biogas is called as digestate. This can be used again as agricultural fertilizer.

Table -3: Chart for Methane content

\begin{tabular}{|c|c|c|c|}
\hline $\begin{array}{c}\text { Sl. } \\
\text { No. }\end{array}$ & Matter & $\begin{array}{c}\text { Litre per kg of } \\
\text { dry matter }\end{array}$ & $\begin{array}{c}\text { \% } \\
\text { Methane }\end{array}$ \\
\hline 1. & $\begin{array}{c}\text { Manure (Human } \\
\text { or Animal) }\end{array}$ & 351 & 60 \\
\hline 2. & Poultry waste & 442 & 65 \\
\hline 3. & Sugar cane waste & 749 & 45 \\
\hline 4. & Maize waste & 800 & 46 \\
\hline
\end{tabular}

\section{Biogas Power Plant}

This technology of biogas is the well-known technology that deals with the production of combustible gas from anaerobic digestion of biodegradable waste. There are many biogas plants installed in the world already. Now, using the biogas for direct combustion in house hold activities for gas stoves or gas lamps is common nowadays, but the power generation by biogas is still relatively rare in most of the countries. In some countries like Germany, the power generation through biogas plant is the main purpose and has become the standard technology.

This paper can discuss the potentials, obstacles and necessary framework conditions for the use of biogas for little and medium scale electricity generation in Republic of India.

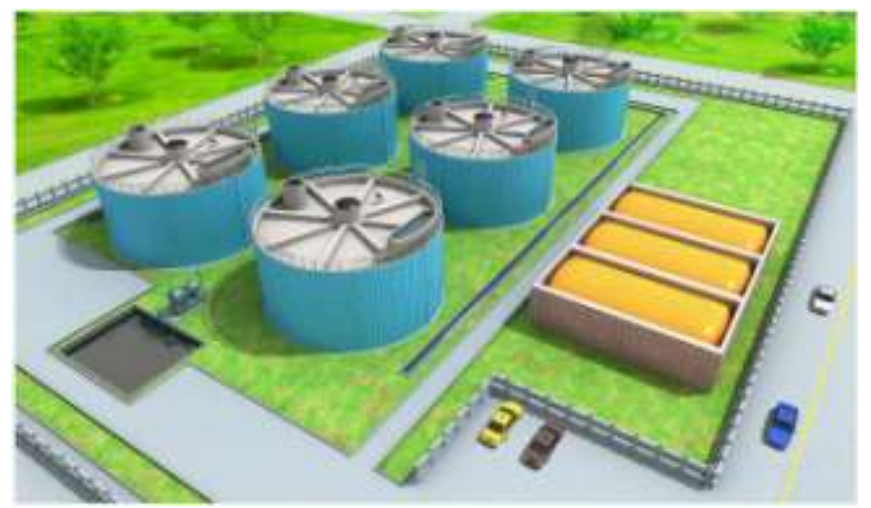

Fig -4: Biogas Power Plant

The figures of gas production on daily basis from the available dung in tropical countries can be calculated from the approximate following values:

- 40 liters biogas per $\mathrm{kg}$ of cattle dung

- 30 liters biogas per $\mathrm{kg}$ of buffalo dung

- 60 liters biogas per $\mathrm{kg}$ of pig dung

- 70 liters biogas per $\mathrm{kg}$ of chicken drops
According to analysis done in one district of Maharashtra. There are approximately 20 Million cattle and 2 Million human population in the in the single district of Maharashtra, which produces 400 Million $\mathrm{kg}$ of cattle dung and 1 Million $\mathrm{kg}$ of human manure approximately. This waste can be utilized for the power generation by converting it to a biogas.

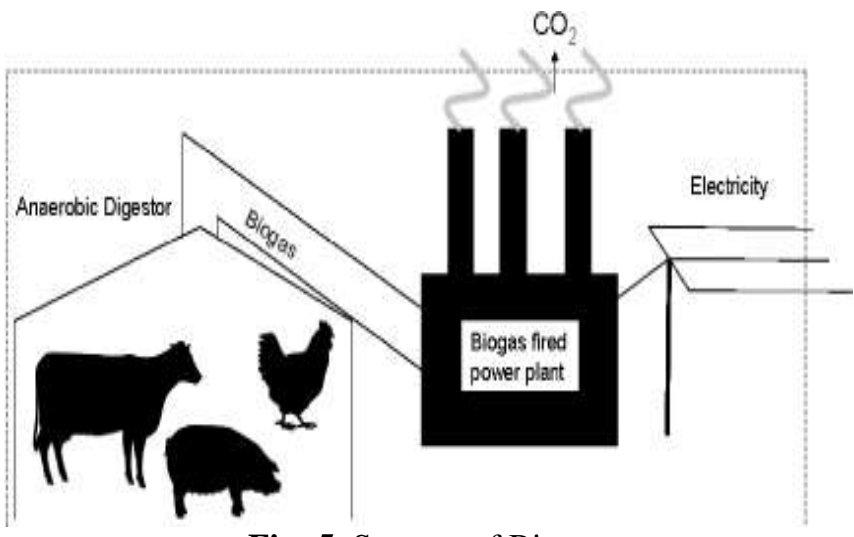

Fig -5: Sources of Biogas

\subsection{Construction Biogas Power Plant}

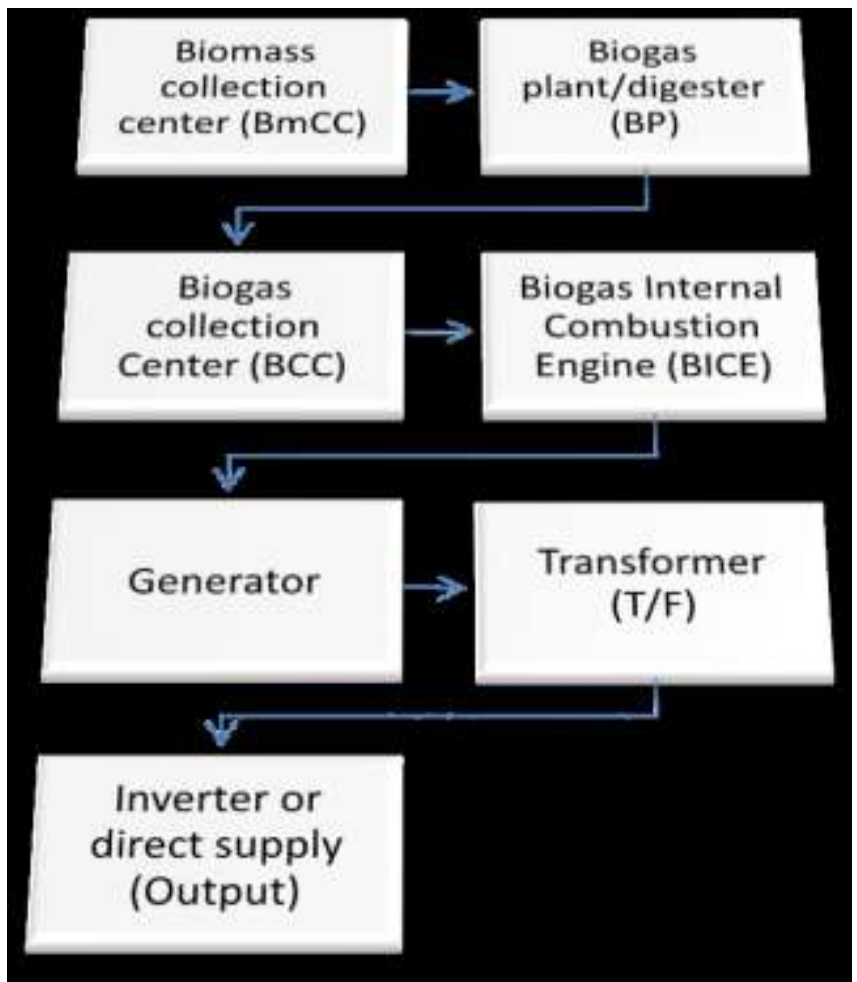

Fig -6: Flow Chart of Biogas Power Plant

a) Assortment center: the gathering center is little and moveable, created of steel. It's characterized by sloping floor and a mechanical device screw mechanism to get rid of the waste.

b) Biogas Plant (Digester): The sterilizer consists of a floating glass/plastic dome enclosure the biogas and therefore the biomass thereunder. AN outlet is provided for the gas to flow. A gage is hooked up to watch the developing pressure underneath the dome. 
c) Biogas assortment Center: The made biogas is quickly unfree here for any use and to avoid escape of gas.

d) Biogas I.C. Engine: This particularly designed combustion engine operates for lower hot worth of biogas and generates the mechanical power that's transferred to the electrical dynamo/generator.

e) Generator: Converts energy to current and transfers it to a electrical device.

f) Electrical device: Transformer transforms the current therefore obtained to appropriate level of voltage so it will be used effectively.

g) electrical converter (storage system)/direct provide: The output of the electrical device will be either directly fed to the manage supply or connected to A battery charger to charge A battery for future use or just use AN electrical converter.

\subsection{Operation of Biogas Plant}

The material required for the process of biogas power plant is brought to the plant every day. Minimum two workers are required for the smooth operation of plant. The work can be divided into following tasks:

- Transport of waste materials

- Processing the waste in mixer

- Operation of digester tanks

- Manure pits

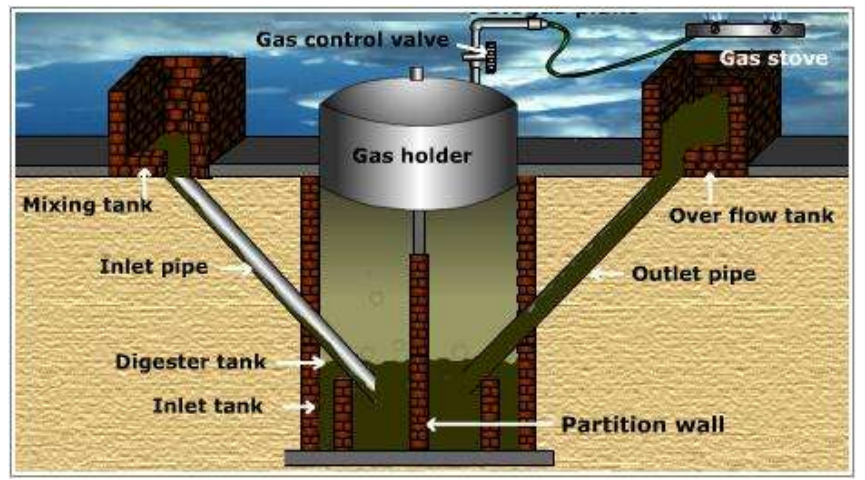

Fig -7: Basic Layout of Biogas Power Project

The biogas contains nearly $50 \%$ to $60 \%$ of methane, which if released in atmosphere will be quite dangerous and can increase the heat 20 times greater than carbon dioxide does. Hence, it can be used for generating energy by combustion which entirely a different matter. Nearly, 40 liters or one cubic meter of biogas can be produced per $\mathrm{kg}$ of cow dung when heated around $30{ }^{\circ} \mathrm{C}$. The amount of gas generated per $\mathrm{kg}$ of cow dung is enough to cook meals for one day for four people in India. A single cow in a single year can produce enough amount of manure, which can be converted in to methane that can match fuel provided by two hundred liters of gasoline. To generate $1 \mathrm{MW}$ of electricity we need nearly 7000 cattle's.

The biogas produced from the biogas plant can be stored and used for power generation. The area required for installing the plant is very less. The mixture of water and cow dung is actually fed into the digester. The solid components in the mixture are around $20 \%$ to $30 \%$. The period of biogas formation is around 3 to 5 days. One kilogram of dung cake can have heat of 375 kilo calories.

Table -4: Dung to Energy

\begin{tabular}{|l|l|l|}
$\begin{array}{l}\text { Dung from } \\
\text { one } \\
\text { Cow/Buffalo }\end{array}$ & $\begin{array}{l}\text { Cow Dung Required } \\
\text { to Produce 1 cubic } \\
\text { meter of Bio Gas }\end{array}$ & $\begin{array}{l}\text { Electricity } \\
\text { Generated from } \\
\text { one cubic meter } \\
\text { Bio Gas per day }\end{array}$ \\
\hline $15-25 \mathrm{~kg}$ & $20 \mathrm{~kg}$ & $2 \mathrm{kw}$ \\
\hline
\end{tabular}

\subsection{Infrastructure Required}

Minimum requirement for the infrastructure of Bio gas plant with capacity of One ton per day of Cow Dung is as follows: Area of Plot: 300 m.sq

Manpower: Two unskilled persons Power supply: $1 \mathrm{KW}$

Water Supply: 1000 to 1500 liters

Cost: Rs. 5 Lacs

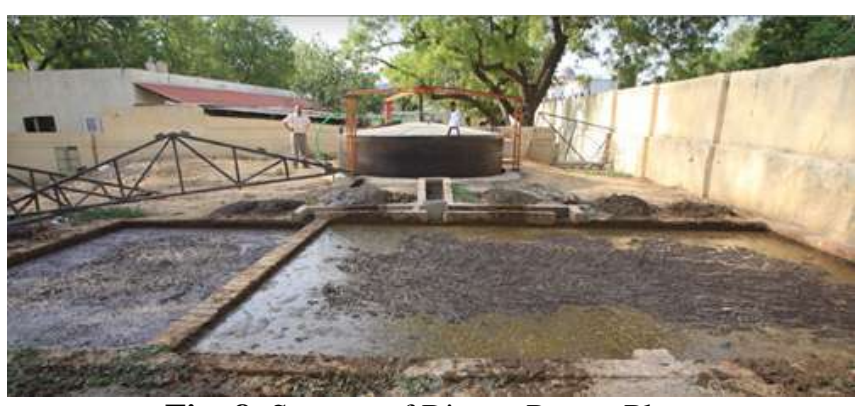

Fig -8: Storage of Biogas Power Plant

\section{Capacity Biogas Power Plant}

The installing capacity of biogas project depends upon the total handling capacity of the plant. The capacity of the biogas plant can be calculated by (Power to be generated in $\mathrm{kW}) \mathrm{x}$ (no. of hours of power generation) $\mathrm{x} 1.2$ = capacity of the biogas plant.

For example, a biogas plant of 85 cum. capacity can generate $10 \mathrm{~kW}$ power for about7 hours (i.e.; 10x7x1.2). About $20 \mathrm{~kg}$ cattle dung is required to produce one cum. biogas.

\section{Dung Biogas Power Plant Potential:}

- No. of cattle capacity: Over 28 Crore.

- Total Dung collected:1400 million ton/day

- Estimated Biogas Production: 60 million $\mathrm{m}^{3} / \mathrm{day}$

\section{Poultry Biogas Power Plant Potential:}

- Total population: 340 million.

- Total Bird litter: 20 million tons/ yr.

- Estimated Biogas Production: 2983 million $\mathrm{m}^{3} / \mathrm{yr}$. 


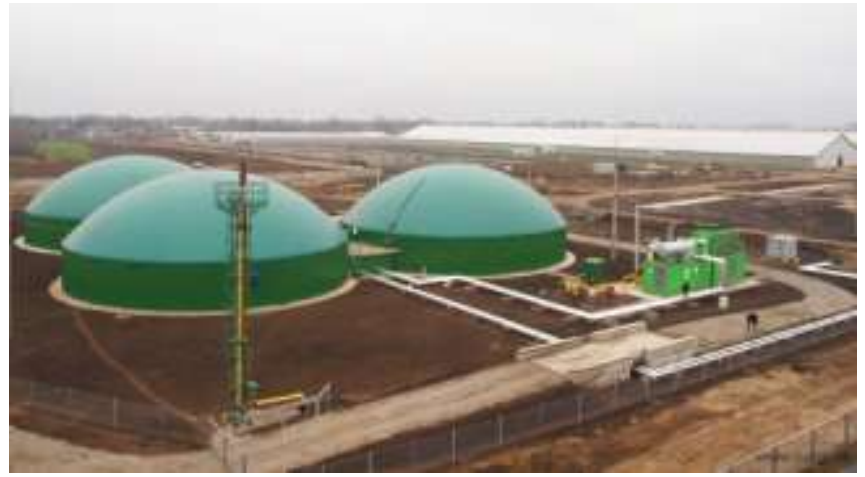

Fig -9: Site of Biogas Power Plant

Table -5: Cost of Biogas Plant

\begin{tabular}{|c|c|c|}
\hline $\begin{array}{c}\text { Sr. } \\
\text { No. }\end{array}$ & $\begin{array}{c}\text { Capacity (cubic } \\
\text { meter) }\end{array}$ & $\begin{array}{c}\text { Approx. Cost } \\
\text { (Rs.) }\end{array}$ \\
\hline 1 & $25 \mathrm{Cum}$ & $3,00,000$ \\
\hline 2 & $35 \mathrm{Cum}$ & $5,00,000$ \\
\hline 3 & $45 \mathrm{Cum}$ & $6,00,000$ \\
\hline 4 & $60 \mathrm{Cum}$ & 7,560000 \\
\hline 5 & $85 \mathrm{Cum}$ & $10,00,000$ \\
\hline
\end{tabular}

The cost of the plant calculated above is approximate assumption excluding land and transmission charges.

- Biogas Plant Capacity: 25 - $3000 \mathrm{cum} /$ day

- Power Generation Capacity: 3 -250 KW

- Power Generation (25 cum Plant): $3 \mathrm{KWhr}$ per day

- Power Generation (100 cum Plant): $12 \mathrm{KWhr}$ per day

\section{Financial analytics of Biogas Power Plant}

State Energy Development Agencies is implementing this theme to push installation of biogas plants in gaushalas, dairies etc. to satisfy their energy demand. The gas is employed for preparation also as for power generation. to push the installation of biogas plant State Govt. is providing monetary help@ four-hundredth of the plant price to the charitable institutes solely. State monetary help and Central monetary help shall be accessible for poultry farms and Commercial/individuals dairies conjointly. The total details of approximate cost of biogas plant and Govt. support is as under:

Table -6: Govt. Support to Biogas Power Plant

\begin{tabular}{|c|c|c|}
\hline $\begin{array}{c}\text { Power } \\
\text { generating } \\
\text { capacity }\end{array}$ & $\begin{array}{c}\text { Biogas plant } \\
\text { capacity }\end{array}$ & Govt. Support \\
\hline Upto $20 \mathrm{~kW}$ & 20 cu. m to 90 cu.m & $40 \%$ of Total Cost \\
\hline Above $20 \mathrm{~kW}$ & $\begin{array}{c}\text { Any combination of } \\
\text { above design }\end{array}$ & $40 \%$ of Total Cost \\
\hline $\begin{array}{c}\text { Above } 100 \mathrm{~kW} \\
\text { (upto } 250 \mathrm{~kW} \text { ) }\end{array}$ & $\begin{array}{c}\text { Any combination of } \\
\text { above design }\end{array}$ & $40 \%$ of Total Cost \\
\hline
\end{tabular}

Table -7: Proposed financial support

\begin{tabular}{|lc|}
\hline Organization & Percentage of Project Cost \\
\hline MNRE support: & $40 \%$ \\
\hline IREDA/ Bank Loan: & $30 \%$ \\
\hline Promoter: & $30 \%$ \\
\hline
\end{tabular}

\section{Economics of Biogas Power Plant}

The global survey of biogas power plant has proved the superiority of the biogas in power generation projects. In some of the cases the profit margin is about 5 to 10 more than the total investments.

Table- 8: Biogas equivalency with Power

\begin{tabular}{|l|l|}
\hline \multicolumn{1}{|c|}{ Biogas capacity } & Power \\
\hline 1 cu. meter of Biogas & 2.0 unit (KWh) \\
\hline Rate of Sale (Net) & Rs 5.0 per unit (KWh) \\
\hline Value & Rs $\mathbf{1 0 . 0}$ \\
\hline
\end{tabular}

\subsection{Project Assumption}

The profit collection of biogas power plant is more than the double. Even with the higher investment with greater capacity of biogas power plant, the profit is acceptable. In the recent time, there is not a single massive biogas power plant in operation in India. This scenario is due to the less awareness and inconvenience of knowledge regarding the biogas project or industrial plant.

Table- 9: Project Assumptions for 1MW plant

\begin{tabular}{|c|c|}
\hline Details & Value \\
\hline Plant Capacity & $1200 \mathrm{Cum} / \mathrm{hr}$ \\
\hline Power Generation Capacity & $1000 \mid \mathrm{KW}$ \\
\hline Project Cost & $5.0 \mathrm{Cr}$ \\
\hline Project Time & 12-18|Months \\
\hline Govt. Support & $40 \%$ \\
\hline Equity Contribution & $30 \%$ \\
\hline Loan & $30 \%$ \\
\hline Interest & $12 \%$ \\
\hline Wet Dung Required per Week & 600-800 Tonnes \\
\hline Land & \begin{tabular}{|l|l|}
$2-3$ & Acres \\
\end{tabular} \\
\hline Full Time Workers & 10-15 Persons \\
\hline Power Generated per hour & $1000 \mid$ KWh (Unit) \\
\hline Power Cost & 4.5 to 5.0 Rs/ KWh (Unit) \\
\hline $\begin{array}{l}\text { Monthly Income by Generation } \\
\text { (@ } 10 \text { hr/day ) }\end{array}$ & 15 Lacs Rs. \\
\hline Fertilizers Sell (tonnes/ week) & 1 Lac Rs. \\
\hline Transportation Cost & $25-30 \mathrm{Rs} / \mathrm{Km}$ \\
\hline PLF (Plant Load Factor) & $90 \%$ \\
\hline Estimated Life & 20 Years \\
\hline Payback Period & $3-4 \mid$ Years \\
\hline
\end{tabular}




\subsection{Pollution Control Equipment's}

Under Income Tax Act, 1961, the specified water and air pollution control equipment's are available at $100 \%$ discounted rate in the first year itself.

Control Equipment's for Air pollution:

- Electrostatic Precipitator.

- Filter System.

- Dust Collector.

- Scrubber System.

- Ash Handling.

- Evacuation System.

\section{CONCLUSIONS}

The bio-methanation station could be a novel innovation for manufacturing electricity from kine dung that otherwise is drained off. These dairies turn out around 5000 thousand tonnes of kine dung once a year. it's advised that farm farmers ought to sell their kine dung to the bio-methanation station. The biogas mitigates a good vary of environmental undesirables to supply top quality organic, provides gas for cookery or electricity generation thereby reducing demand for fuel wood and charcoal for cookery. It improves water quality and mitigates gas emissions. If giant and made farmers type cooperatives and adopt the technology of changing kine dung into electricity, then most of the farm complexes will become self-sufficing in electricity would like and may conjointly offer electricity to the neighboring localities.

\section{REFERENCES}

[1]. MNRE (Ministry of New and Renewable Energy) www.mnre.gov.in/file-manager/UserFiles/faq_biomass.htm [2]. Renewable Energy

https://en.wikipedia.org/wiki/Renewable_energy

[3]. MNRE (Ministry of New and Renewable Energy) http://mnre.gov.in/schemes/offgrid/

[4]. MEDA (Maharshtra Energy Development Agencies) http://www.mahaurja.com/RE_Biomass_plant.html

[5]. Agricultural Economics Research Review Vol. 27

(No.2) July-December 2014 by Anurag Chaudhary* and

Mini Goyal

[6]. Biogas Calculation

http://www.perfectgasgenerators.in/biogas-generator.htm

[1]. Designing an Affordable Power Generation System for

Rural Households in India by Faraz Ahmad, Mohammad

Zaid

[7]. Financial Analysis of Biogas Power Plant

http://gbes.in/financial-analyses-of-biogas-to-bio-cng-

projects-in-india-projections-based-case-study-analyses/

[8]. Biogas Plant by Satish Lele

http://www.svlele.com/biogas.htm

[9]. Biogas-vikaspedia www.vikaspedia.in/energy/energy-

production/bio-energy/biogas

\section{BIOGRAPHIES}

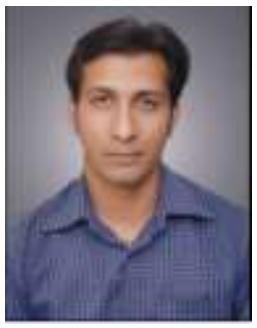

Rajendra Ramchandra Shinde has graduated in Electrical \& Electronics Engineering discipline. He will pursue his Masters from Electrical Engineering discipline in 2016. He is also a H.O.D of Electrical Engineering discipline in Adarsh Institute of Technology (Poly), vita

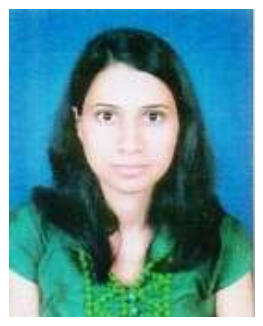

Ashwini Dilip Patil has graduated in Electrical Engineering discipline. $\mathrm{He}$ is also a Sr. Lecturer of Electrical Engineering discipline in Adarsh Institute of Technology (Poly), vita.

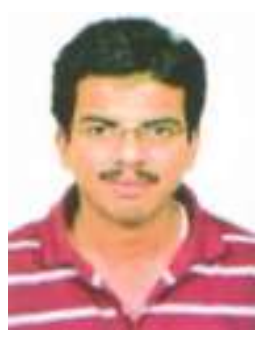

Prasad Jaysingh Yadav has graduated in Electrical Engineering discipline. He will pursue his Masters from Power Systems discipline in 2016. He is also a Sr. Lecturer of Electrical Engineering discipline in Adarsh Institute of Technology (Poly), vita. 